\title{
Procedural Fairness and Efficiency in International Arbitration
}

\author{
Fabricio Fortese ${ }^{*}$ and Lotta Hemmi ${ }^{* *}$
}

DOI: $10.21827 / 5 \mathrm{a} 86 \mathrm{a} 89 \mathrm{~d} 8 \mathrm{e} 651$

\section{Keywords}

DUE PROCESS; ARBITRATION; EFFICIENCY

\begin{abstract}
Procedural due process requires all legal proceedings to be fair and that every party involved is given notice of the proceedings, are treated equally, and are given an opportunity to be heard and to deal with the case of its opponent before a decision is made by a lawfully constituted tribunal or decision maker. However, while the mandatory due process requirements are of utmost importance within international arbitration, where are its limits? How far shall the equal treatment and procedural fairness go, and can it happen at the expense of procedural efficiency? The users of international arbitration tend to be concerned on the delays and high expenses of arbitration. A recurrent complaint is the 'judicialisation' of arbitration; that the procedure is becoming as equally formal dispute resolution proceeding as litigation. Simultaneously, the international arbitration field has been promoting arbitral cost and time efficiency, by incorporating relevant provisions to national arbitration laws, institutional arbitration rules and to other soft law elements. This contribution addresses the balance between the requirements of due process and efficiency within international arbitration.
\end{abstract}

\section{Introduction}

The concept of due process traces its origins back to the English common law system. The rule, first accepted in England, that individuals shall not be deprived of life, liberty, or property without legal authority and an opportunity to defend themselves pre-exists written constitutions. King John's Magna Carta (1215) defined the rights of English subjects against the authority of the king and is an early example of a 'constitutional' guarantee of due process. Charter 39 declares that '[n]o free man shall be seized, or imprisoned ... except by the lawful judgment of his peers, or by the law of the land...'. The phrase 'due process of law' appeared as a substitute for the Magna Carta's 'the law of the land', in a statute of King John's successor (King Henry III) that restated Magna Carta's guarantee of the liberty of the subject. ${ }^{1}$ Due process requirements are therefore

Fabricio Fortese is a lawyer and adjunct lecturer in international arbitration law at the Department, Stockholm University.

** Lotta Hemmi is an associate lawyer in the Dispute Resolution Group at Hannes Snellman, Helsinki. The views presented are exclusively those of the author and do not reflect the views of the affiliated law firm or its clients.

1 The Carta Magna as we know it today is considered to have been re-invented by Sir Edward Coke, in the seventeenth century. For further details, see UK Supreme Court, Lord Sumption, Magna Carta then 
considered to be constitutional guarantees of an individual in relation to the State and authorities.

The application of constitutional due process is traditionally divided into two categories: a) substantive due process, and b) procedural due process. These categories derive from a distinction made between two types of law. On the one hand, substantive law creates, defines and regulates rights. On the other, procedural law refers to the formal steps to be taken in enforcing substantive law. Thus, procedural due process is understood to set limits on the exercise of power by the State by requiring that it follow certain rules.

Procedural due process requires all legal proceedings to be fair and that each party involved is given notice of the proceedings, treated equally, and given an opportunity to be heard and to deal with the case of its opponent before a decision is made by a lawfully constituted tribunal or decision maker. Considerations of due process are also relevant in international arbitration, even where a State is not involved in the dispute as a party. This contribution will only address issues of procedural (and not substantive) due process in the context of international arbitration, and its tensions with 'efficiency of the procedure'.

While the mandatory due process requirements are of utmost importance within international arbitration, where are the limits? How far shall the equal treatment and procedural fairness go, and can it happen at the expense of procedural efficiency?

The users of international arbitration tend to be concerned about the delays and high expenses of arbitration. A recurrent complaint is the 'judicialisation' of arbitration, that is, the procedure becoming as equally formal dispute resolution proceeding as litigation. ${ }^{2}$ Simultaneously, the international arbitration field has been promoting arbitral cost and time efficiency by incorporating relevant provisions into national arbitration laws, institutional arbitration rules and to other soft law elements. Thus, the balance between the requirements of due process and efficiency within international arbitration are addressed in this contribution.

\section{Due Process in International Arbitration}

Arbitration is not a product of contemporary but of antique times. Commercial disputes were settled by resorting to arbitration in ancient Egypt, ${ }^{3}$ Greece $^{4}$ and Rome. ${ }^{5}$ Its contemporary and most comprehensive definition is perhaps the one that describes arbitration as a "process by which parties consensually submit a dispute to a nongovernmental decision maker, selected by or for the parties, who renders a binding decision finally resolving the dispute in accordance with neutral, adjudicative procedures

and now, Address to the Friends of the British Library, 9 March 2015, at <supremecourt.uk/docs/speech150309.pdf $>$ (accessed 21 March 2015).

2 Queen Mary, University of London, School of International Arbitration and PwC, REPORT: International Arbitration Survey 2013: Corporate Choices in International Arbitration: Industry Perspectives (2013), at <pwc.com/gx/en/arbitration-dispute-resolution/index.jhtml> (accessed 21 April 2015).

3 Mantica, M, "Arbitration in Ancient Egypt", 12 Arbitration Journal (1957) 155, 158-160: Where the author describes examples of arbitration clauses to resolve disputes in funerary trust agreements dated as far as $2500 \mathrm{BC}$.

4 Roebuck, D, Ancient Greek Arbitration (Holo Books, Oxford, 2001). See also Velissaropoulos-Karakostas, J, "L'arbitrage dans la Grèce antique - Epoques archaïque et classique", 1 Revue de l'Arbitrage (2000) 9, 18-26: where the author outlines the arbitral procedure in Greece in the 4th and 5th century BC.

5 Stein, PG, "Arbitration Under Roman Law", 41 Arbitration: The Journal of the Chartered Institute of Arbitrators (1974) 203. 
affording the parties an opportunity to be heard' ${ }^{6}$ However, there are numerous other definitions of international arbitration. ${ }^{7}$

A fundamental feature of arbitration is that the arbitral award is a final and binding determination of the parties' disputes. Arbitral awards are widely recognised and enforced, even internationally. In fact, the entire justification of international arbitration is founded on the international enforceability of arbitral awards under the New York Convention on the Recognition and Enforcement of Foreign Awards, which has been ratified by 154 States. $^{8}$ For the international enforceability to happen, States indirectly delegate jurisdictional powers to arbitral tribunals through the recognition of the parties' agreement. With this delegation of powers comes a type of trade-off in the form of minimum quality standards of procedural safeguards or 'due process' ${ }^{9}$ This is mainly because by opting for arbitration, parties to a dispute waive their constitutional rights to have their dispute heard by a national court. ${ }^{10}$ Therefore, as arbitration is a kind of substitute for court procedure, some procedural standards need to be met to compensate for the loss of access to a court. ${ }^{11}$ Outsourcing the adjudicatory public functions of a sovereign State calls for observance of the most essential rules of procedure, that is, due process.

Consequently, due process in international arbitration requires, first, that the parties' agreement to arbitrate their dispute will be respected and enforced, that they will effectively have access to arbitration as their chosen means of justice, and that they will have a meaningful opportunity to participate in the lawful constitution of the arbitral tribunal. The core guarantees of procedural due process comprise the arbitrator's duty to treat the parties equally, fairly and impartially, and to ensure that each party has an opportunity to present its case and deal with that of its opponent. It also comprises the arbitral tribunal's duty to deal with all of the issues that are put to it. Therefore, access to arbitration is not enough; the procedure itself must also be fair.

\section{II.1. International Framework of Due Process}

An important question then is what are the sources of due process in international arbitration. Are the (constitutional) safeguards of due process found in State court systems also applicable to arbitration proceedings? Even though national arbitration laws impose due process requirements, these laws do not provide a comprehensive definition of due process. And even though there seems to be a general consensus on the importance of due process guarantees in international arbitration, its exact meaning, parameters and details vary from one legal system to another. Not only national legislation but also international arbitration conventions recognise and impose requirements of due process. They do so by denying recognition and enforceability of

6 Born, G, International Commercial Arbitration (Kluwer Law International, Leiden, 2014), 291.

7 Lew, JDM, Mistelis, LA and Kröll, SM, eds, Comparative International Commercial Arbitration (Kluwer Law International, Leiden, 2003), 1-5.

8 United Nations Commission on International Trade Law (UNCITRAL), Status of the Convention on the Recognition and Enforcement of Foreign Arbitral Awards (1958), at $<$ uncitral.org/uncitral/en/uncitral_texts/arbitration/NYConvention_status.html> (accessed 21 April 2015).

9 Kurkela, M, and Turunen, S, Due Process in International Arbitration (Oxford University Press, Oxford, 2010), 201.

10 Lew et al, supra nt 7, 5-34.

11 Kurkela and Turunen, supra nt 9, 2. 
arbitral awards if basic essential elements of procedural fairness have not been satisfied. ${ }^{12}$ Therefore, it has been said that the law of arbitration is the law of the enforcement. ${ }^{13}$

Even enforceability, as the criterion to provide a unique and inclusive definition of due process, proves to be challenging. ${ }^{14}$ The enforcement of an award may be refused ex officio ${ }^{15}$ by a competent court or it may require the action of the party against whom the enforcement is sought. The unenforceability may be automatic and cannot be remedied, 16 or it could be remedied by the lapse of time. ${ }^{17}$ An award could be enforceable in one jurisdiction but not in another. ${ }^{18}$

If rules of procedure vary among jurisdictions, and may even have a different hierarchy and weight within a single jurisdiction, how should due process in a given arbitration be identified and defined? Are the due process safeguards in international arbitration linked to those of any national legal system? In that case, would it be the legal system of the seat of the arbitration, the place where the actual arbitration is conducted or certain evidence is produced, as the place where the award will potentially be enforced? Conversely, are there international, delocalised, procedural rules in arbitration? If so, would national courts be bound to respect them when hearing challenges against the award or its enforcement?

\section{II.2. Procedural Freedom}

One of the hallmarks of arbitration is the parties' power to shape the arbitration proceedings. The United Nations Commission on International Trade Law (UNCITRAL) Model Law on International Commercial Arbitration (Model Law), ${ }^{19}$ as all other national and international arbitration legislation, guarantees the freedom of the parties to tailor what rules of procedure will be implemented, subject to a few mandatory provisions containing the general due process requirements. ${ }^{20}$ The parties may tailor the proceedings by preparing their own individual set of rules or by referring to standard rules of arbitration institutions. These laws also empower arbitrators to conduct the arbitration in such a manner, as they consider appropriate, if the parties were silent or have failed to reach an agreement. ${ }^{21}$ These powers of the arbitrators include the power to determine the admissibility, relevance, materiality and weight of any evidence.

Autonomy of the parties in determining the rules of procedure is of special importance in international cases, since it allows the parties to select the rules according to their specific wishes and needs, without restrictions imposed by traditional and possibly

12 Article V(1)(b), United Nations, Convention on the Recognition and Enforcement of Foreign Arbitral Awards (1958) 330 UNTS 3 (New York Convention); Article IX-1(b), European Convention on International Arbitration (1961) 484 UNTS 349; Article 5.1.b, Organization of American States (OAS), Inter-American Convention on International Commercial Arbitration; see also Born, supra nt 6, para 26.05. [3].

13 Petrochilos, G, Procedural law in International Arbitration (Oxford University Press, Oxford, 2004), 39.

14 Kurkela and Turunen, supra nt 9, 4.

15 Section 55, Swedish Arbitration Act, Sweden (1999) SFS 1999, 116; Article 35(2), UNCITRAL, UNCITRAL Model Law on International Commercial Arbitration, 1985 with amendments as adopted in 2006 (Model Law). See also National Commercial Court of Appeal of Argentina, American Restaurants Inc y otros v Outbank Steakhouse Int, 20 April 2011, La Ley 2011, B, 593, AR/JUR/29420/2010.

16 Section 33, Swedish Arbitration Act.

17 Article 34(3), Model Law.

18 Article V(2)(a), New York Convention.

19 UNICTRAL, Model Law on International Commercial Arbitration (1985 with amendments from 2010).

20 Article 19, Model Law. The most fundamental provisions that the parties cannot derogate from are those of procedural fairness, eg., Article 18 Model Law.

21 Ibid. 
conflicting domestic concepts, thus obviating the risk of surprises. The supplementary discretion of the arbitral tribunal recognised in the Model Law is equally important, as it allows the tribunal to tailor the conduct of the proceedings to the specific features of the case, without being hindered by any restraint that may stem from local law, including any domestic rule on evidence. ${ }^{22}$ Also, it provides grounds for displaying initiative in solving procedural questions not regulated in the arbitration agreement or the applicable arbitration law.

Under the label of party autonomy, States have left wide areas of arbitration law unregulated. Paradoxically, this lack of regulation has not resulted in fewer rules. On the contrary, private actors have occupied the space left by States with often dense and highly detailed soft law rules. ${ }^{23}$ Some have seen this as a loss of one of the beauties of arbitration. ${ }^{24}$ On the opposite side are those who see this as a positive trade of flexibility for predictability. ${ }^{25}$

Soft law norms are generally understood to be those that cannot be enforced by public force. These norms can emanate from State actors, be they legislators, governments or international organisations. These can also emanate from non-State actors, such as private institutions and professional or trade associations with an international character. ${ }^{26}$ In the international arbitration arena, numerous guidelines, standards and codes of 'best practices' for the conduct of the proceedings have been issued by groups such as the Chartered Institute of Arbitrators, the International Bar Association, the International Chamber of Commerce, the International Law Office, UNCITRAL and the American Arbitration Association.

In spite of the lack of enforceability, the addressees of soft law norms can perceive it as binding and, even if they do not, they may choose to abide by it of their own accord. ${ }^{27}$ This normative weight is enhanced when soft law rules are codified. Soft law codification serves a useful purpose in increasing procedural uniformity, certainty and predictability amongst parties from different judicial traditions. ${ }^{28}$

And even national (hard) laws in arbitration are drafted according to international conventions, guidelines, and 'model laws'. Also, given that arbitration is the dispute resolution method most used for cross-border dealings, the users, arbitrators and cases are international too. Therefore, national procedural rules and guarantees cannot apply exclusively In her often-cited paper - Globalization of Arbitral Procedure, Professor Gabrielle Kaufmann-Kohler comments that the globalisation of arbitration occurs primarily under the auspices of national arbitration laws, in a classical fashion, and that

22 Other provisions in the Model Law recognise party autonomy and, failing agreement, empower the arbitral tribunal to decide on certain matters. For example, on issues related to the place of the arbitration (Article 20) and the language to be used in the proceedings (Article 22).

23 Park, WW, "The Procedural Soft Law of International Arbitration: Non-governmental Instruments" in Mistelis, LA and Lew, JDM, Pervasive Problems in International Arbitration (Kluwer International, Leiden, 2006), 146-147: where Park discusses the problem under the name of 'judicialisation' of international arbitration.

$24 I d, 141$.

$25 I d, 149$.

26 Kaufmann-Kohler, G, "Soft Law in International Arbitration: Codification and Normativity", 1(2) Journal of International Dispute Settlement (2010) 284.

27 Ibid.

28 Id, 299. 
globalisation of the arbitral procedure is possible thanks to the freedom that various national legislations grant to the parties and to the arbitrators. ${ }^{29}$

Therefore, cross-legal approaches, similar to those that exist for substantive law should be observed in cross-border disputes. It does not come as a surprise then that some scholars advocate that the law of due process in international arbitration has a structure or character similar to that of the law developed by merchants, called lex proceduralia.

Like lex mercatoria, the due process in international arbitration (lex proceduralia) would be a set of norms that floats above national jurisdiction and various systems of soft law. ${ }^{30}$ Lex proceduralia also refers to the international and customary nature of the body of law in question instead of being just a part of the national formally valid system of norms. ${ }^{31}$

Although the internationalisation of due process is present in different arbitration laws and institutional rules around the globe, the specifics of those provisions differ in practice.

\section{II.3. The Due Process Guarantees in Different Arbitration Laws}

Article 18 of the Model Law embodies the principles that the parties shall be treated with equality and given a full opportunity of presenting their case. The English Arbitration Act does not adopt the same qualifier (full opportunity). Instead, it requires that the parties have a reasonable opportunity. ${ }^{32}$ In France, the law provides that 'the arbitral tribunal shall rule after having heard the parties or having given them the opportunity to be heard'. Similarly, in the Netherlands, the arbitration law imposes on the arbitral tribunal the obligation to give each party 'an opportunity to substantiate his claims and to present his case'. In Switzerland, 'the Arbitral tribunal shall ensure ... the right of both parties to be heard...'. Equally, in Sweden, 'the arbitrators shall afford the parties, to the extent necessary, an opportunity to present their respective cases...'.

As noted by the secretariat of UNCITRAL, a number of provisions in the Model Law illustrate the parties' fundamental procedural rights. For example, Article 24(1), which deals with the general entitlement of a party to oral hearings, provides that, unless the parties have agreed that no oral hearings be held for the presentation of evidence or for oral arguments, the tribunal shall hold such hearings at an appropriate stage of the proceedings, if so requested by a party.

Another illustration of procedural fairness is Article 24(3) of the Model Law, which provides that all statements, documents and other information supplied by a party to the tribunal shall be communicated to the other party, and that any expert report or evidentiary document on which the arbitral tribunal may rely in making its decision shall be communicated to the other parties. Something similar is provided for in relation to the evidence of a tribunal-appointed expert. In these cases, the Model Law requires the expert, after delivering his or her report, to participate in a hearing where the parties may

29 Kaufmann-Kohler, G, "Globalization of Arbitral Procedure", 36 Vanderbilt Journal of Transnational Law (2003) 1313.

30 Kurkela and Turunen, supra nt 9, 8. See also Smit, H, "Proper Choice of Law and Lex Mercatoria Arbitralis" in Carbonneau, TE, ed, Lex Mercatoria and Arbitration: A Discussion of the New Law Merchant (Transnational Publishers Inc, New York, 1990), 59; Gaillard, E, Legal Theory of International Arbitration (Martinus Nijhoff, Leiden, 2010), 1-10.

31 Id, 202.

32 Section 33(1)(a), Arbitration Act 1996, England; Article 1485, Code de procédure civile (Civil Code of Procedure), France (2005); Article 1039, Dutch Arbitration Act, The Netherlands (1986); Article 182, Private International Law Act 1987 Chapter 12 - International Arbitration, Switzerland; Section 24, Swedish Arbitration Act. 
put questions to the expert and present expert witnesses to testify on the points in dispute, if such a hearing is requested by a party or the tribunal deems it needed. ${ }^{33}$ In order to enable the parties to be present at any hearing and at any meeting of the tribunal for inspection purposes, the parties must be given notice in advance. ${ }^{34}$

International norms on proper procedures enhance the substantive correctness and legitimise decisions. The better the parties' opportunities to provide the basis for the decision, the more correct the substantive outcome is likely to be. Even a good and correct result does not compensate for a bad and unfair procedure. ${ }^{35}$

Counsels at various businesses have voiced the importance of a fair outcome in every dispute, but a fair result has to be solidly backed-up by a set of legal rules. This is to allow corporate counsels accurately to manage their dispute resolution risk assessment ex-ante. In other words: 'fairness yes, commerciality yes, but via a predictable route.'36

Guaranteeing the parties' access to arbitration, and treating them fairly and ensuring they have an opportunity to present their cases also forms part of an arbitrator's obligation owed to the parties. In managing cases, due process needs to be balanced against the arbitrator's duty to ensure the efficient and timely completion of their mandate to resolve the dispute. Could there be a conflict between procedural fairness and efficiency? Does procedural fairness increase costs? If so, is it efficient to leave aside some formalities and focus on the substance of the dispute? Increasing costs may even be seen as putting limits to access to arbitration and thus to justice, for those parties with weaker financial muscle.

Therefore, fairness also requires some degree of efficiency, since justice too long delayed becomes justice denied. Equally, without fairness an arbitral proceeding could hardly be considered an efficient mechanism of dispute resolution.

\section{Efficiency in International Arbitration}

Without making a generalisation regarding the needs of the users of arbitration, an ideal arbitration would be simultaneously conducted in an equal, neutral, flexible, costefficient and rapid manner while tailored to the particularities of each dispute. Efficiency is often assimilated with only cost and time efficiency, but the other side of the same coin is to gain the efficient proceedings without risking either the correct outcome or the due process. ${ }^{37}$ Parties to arbitration are obviously not after a cheap dispute resolution process at the expense of a well-founded outcome. At its best, an efficient arbitration process can be equivalent to good case management and thereby result in a correct outcome. It does not have to be an 'either ... or' scenario.

The relation between parties' procedural autonomy and the mandatory requirements of due process has been discussed above, but the third dimension of the same topic is the efficiency of arbitrations. How can the objectives of efficiency be aligned with the

\footnotetext{
Article 26(2), Model Law.

Article 24(2), Model Law.

35 Kurkela and Turunen, supra nt 9, 203.

36 The Arbitration Institute of the Stockholm Chamber of Commerce, Nappert S, Commentary on the Corporate Counsel Panel Discussion, at The Stockholm Arbitration Summit: The Role of Law, 22 May 2014, Sweden.

37 Newmark C, "Controlling Time and Costs in Arbitration" in Newmark, C, ed, Leading Arbitrators Guide (Juris Publishing, New York, 2006), 81; Risse, J, "Ten Drastic Proposals for Saving Time and Costs in Arbitral Proceedings", 23(3) Arbitration International (2013) 5: where Risse considers the quality as an alternative to saving time and costs.
} 
requirements of arriving to a 'correct', enforceable arbitral award and the requirements of due process? The concept of efficient arbitration entails numerous features, which are explained below.

The efficiency-related formal discussions first arose over two decades ago around the issue of disruption and delays in arbitration proceedings. ${ }^{38}$ The obstructive tactics of recalcitrant parties are of course an unfortunate reality of arbitrations, as well as an acknowledged procedural feature. Back in 1990, Working Group I on Preventing Delay and Disruption of Arbitration discussed different ways of combating disruption at an International Council for Commercial Arbitration (ICCA) Congress held in Stockholm. These ways covered the issues of appointment of arbitrators and conduct of the proceedings, among other matters. ${ }^{39}$ As a result of the congress, the following means of preventing obstruction in arbitrations were decided upon:

1. Arbitrating in an arbitration-friendly seat where the legislation provides fewer opportunities for obstruction

2. Using arbitration rules designed to prevent delay and disruption

3. Using the possibility to supplement the rules by additional agreements under party autonomy

4. Appointing arbitrators 'courageous enough' to use their procedural discretion

5. Arbitrating under an institution's administration. ${ }^{40}$

These criteria may seem almost trivial in 2015, but they entail the core essence of efficient arbitration even today. The discussions in that congress cemented the foundations, and the 'construction work' was erected on these corner stones.

Only four years later, at the 1994 ICCA Congress in Vienna, the discussion had already been taken further. The Working Group then debated the advantages and disadvantages of reforming detailed arbitration laws and rules. The fear was that excessively detailed arbitration statutes and rules would only give reason to an increasing number of challenge proceedings, delays and costs. ${ }^{41}$ This would have naturally been the exact opposite of the objectives of efficient arbitral proceedings. The core conclusion of the discussions around that congress was that the regulating should not result in complicating arbitrations, but in simplifying them. It was stated that in order to enhance efficiency, one should consider whether some cases should have only one arbitrator instead of three and how to procedurally deal with summary proceedings and interim

38 International Council for Commercial Arbitration (ICCA), Working Group I, Preventing Delay and Disruption of Arbitration ICCA Congress, Stockholm, 1990; Working Group I, Planning Efficient Arbitration Proceedings, ICCA Congress, Vienna 1994.

39 Holtzmann, HM, "How to Prevent Delay and Disruption of Arbitration: Lessons of the 1990 ICCA Stockholm Congress" in van den Berg, AJ, ed, Preventing Delay and Disruption in Arbitration and Effective Proceedings in Construction Cases: International Congress Proceedings (ICCA Congress Series No 5) (Kluwer Law International, Leiden, 1991), 21-22.

40 Ibid.

41 Marriott, AL, "Pros and Cons of More Detailed Arbitration Laws and Rules" in van den Berg, AJ, ed, Planning Efficient Proceedings: The Law Applicable in International Arbitration (ICCA Congress Series No7) (Kluwer Law International, Leiden, 1996), 71. 
measures. He had a practical approach to developing functional soft law, stating that '[w]e must have rules which reduce the need for and time spent in hearings, but not as a result increasing the volume of documents and written submissions. ${ }^{4} 2$

These concerns and the suggestive course of direction raised in 1994 were developed even further. The international arbitration community is headed towards the said goals and discussion has become more intense around the topic. The culmination point for the multiple discussions on efficiency of arbitration has so far been the 2007 publication, Techniques for Controlling Time and Costs in Arbitration, which is a report by the International Chamber of Commerce (ICC) Commission on arbitration. ${ }^{43}$ The purpose of the report was to encourage parties involved in arbitration to make mutual and conscious decisions in the early stages of arbitration on the conduct of the proceedings. The Report was practically implemented in the renewed arbitration rules of the ICC, which came into force on 1 January 2012. Thereafter the ICC has published a second edition of the Report to reflect the various modifications made in the 2012 ICC Rules of Arbitration (ICC Rules). ${ }^{44}$

The ICC was not the first to promote the efficiency of arbitration by incorporating provisions related thereto, but because the ICC rules are a universally acknowledged signpost in international arbitration, its impact has major significance. One of the guiding principles of the new ICC rules was improving the time and cost efficiency of arbitration. ${ }^{45}$ The ICC has been proactively identifying the importance of effective case management as the ICC Commission has also published a guide for in-house counsel and other party representatives on effective arbitration case management in early 2015.46 This publication naturally contributes to the standardisation of the soft law on the rules of arbitral efficiency.

From the parties and counsels perspective, the International Bar Association has also issued Guidelines on Party Representation in International Arbitration (2013), ${ }^{47}$ which are inspired by the principle that party representatives should act with integrity and honesty, and should not engage in activities designed to produce unnecessary delay or expense, including tactics aimed at obstructing arbitration proceedings.

Alongside the ICC, other international arbitration institutes that have recently revised their arbitration rules have developed rules favouring efficiency. For example, the 2014 rules of the London Court of International Arbitration (LCIA) (LCIA Rules) also explicitly aim to promote efficiency in arbitration. ${ }^{48}$ The rules empower arbitral tribunals

$42 \quad I d, 72$.

43 International Chamber of Commerce (ICC) Commission on Arbitration and ADR, Task Force on Reducing Time and Costs in Arbitration, REPORT: Techniques for Controlling Time and Costs in Arbitration, 2007.

44 International Chamber of Commerce (ICC) Commission on Arbitration and ADR, Task Force on Reducing Time and Costs in Arbitration, REPORT: Techniques for Controlling Time and Costs in Arbitration, (2nd ed, 2014) at <iccwbo.org/Advocacy-Codes-and-Rules/Document-centre/2012/ICCArbitration-Commission-Report-on-Techniques-for-Controlling-Time-and-Costs-in-Arbitration/> (accessed 30 April 2015).

45 See Articles 22-24 and Appendix IV, ICC, ICC Rules of Arbitration, (2012) in force as of 1 January 2012 (ICC Rules).

46 ICC Commission on Arbitration and ADR, REPORT: Effective Management of Arbitration - A Guide for In-House Counsel and Other Party Representatives (2015). See also, Grierson, J, and van Hooft, A, Arbitrating under the 2012 ICC Rules (Kluwer Law International, Leiden, 2012), 7.

47 International Bar Association, Guidelines on Party Representation in International Arbitration (2013) at $<$ ibanet.org/Publications/publications_IBA_guides_and_free_materials.aspx> (accessed 10 May 2015).

48 Sabharwal, D, and Zaman, R, "Vive la difference? Convergence and Conformity in the Rules Reforms of Arbitral Institutions: The Case of the LCIA Rules 2014", 31(6) Journal of International Arbitration 
with procedural discretion to avoid unnecessary delay or expense for the sake of a 'fair, efficient and expeditious means for the final resolution of the dispute' ${ }^{49}$

While taking steps towards arbitration rules in favour of efficiency, arbitration institutions have had to bear in mind the founding requirement of international enforceability of arbitral awards. As the drafters have had to balance between the objectives of efficiency and fairness, we are currently closer to a universal consensus than ever before. However, analysing the efficiency related provisions in recently revised arbitration rules leads to an interesting outcome. A distinction can be made between the two categories of arbitral efficiency: a) regulatory means of promoting explicit default efficiency; and b) authorisation for the tribunal's discretion regarding the conduct of the proceedings. Both of the categories are naturally subject to party autonomy and the mandatory requirements of due process, but what do they actually mean?

\section{III.1. Explicit Default Efficiency}

By the first category, the authors refer to provisions actually incorporated into arbitration laws, rules or agreements. One of the most explicit efficiency-related issues is the default number of arbitrators in the arbitral tribunal. A three-member arbitral tribunal causes higher fee costs compared with a sole arbitrator, and it also causes reconciliation difficulties as to three individuals' schedules. It is undisputedly impractical to have a default arbitral tribunal consisting of three arbitrators deciding a subjectively small and simple dispute.

Nevertheless, the Model Law maintains the classical approach in relation to the number of arbitrators. According to Article 10(2), and similarly to other national arbitration acts, 50 the number of arbitrators shall be three if the parties fail to determine the number themselves.

However, this line of regulation does not reflect a unanimous understanding of modern requirements of default efficiency. There is also legislation to the contrary. For instance, according to Section 15(3) of the English Arbitration Act (1996), the tribunal shall consist of a sole arbitrator if there is no agreement as to the number of arbitrators. Similarly, Section 5 of the US Federal Arbitration Act foresees a single arbitrator as the default, unless otherwise provided in the agreement by the parties. This line of regulation promotes efficiency in a straightforward manner, by setting a higher threshold for establishing a three-member tribunal.

The sole arbitrator as the default rule of a legislative model also reflects the trend of international arbitration institutions. Article 12 of the ICC Rules states that, where the parties have not agreed upon the number of arbitrators, the Court shall appoint a sole arbitrator. Similarly, according to Article 5.8 of the LCIA Rules from 2014, a sole arbitrator shall be appointed unless the parties have agreed in writing otherwise. ${ }^{51}$

(2014) 707; London Court of International Arbitration (LCIA), LCIA Arbitration Rules, effective 1 October 2014 (LCIA Rules).

49 Article 14.4(ii), LCIA Rules.

50 See eg., Sections 12(2) and 13, Swedish Arbitration Act; Section 1034(1), Code of Civil Procedure, Germany (2005) Federal Law Gazette I, 3202, last amended by Article 1 of the Act of 10 October 2013, Federal Law Gazette I, 3786.

51 See also Article 6.1, Singapore International Arbitration Centre (SIAC), Arbitration Rules of the Singapore International Arbitration Centre (5th ed, 2013); Article 16, Finland Chamber of Commerce (FAI), Arbitration Rules of Finland Chamber of Commerce (2013) (FAI Rules). 
Despite this, the United Nations Commission on International Trade Law (UNICTRAL) Arbitration Rules as revised in $2010^{52}$ (UNCITRAL Rules) still set a default tribunal of three arbitrators if the parties have not agreed that there should be only one. ${ }^{53}$ Similarly, the Article 12 of the 2010 Arbitration Rules of the Arbitration Institute of the Stockholm Chamber of Commerce (SCC Rules) ${ }^{54}$ establishes that where the parties have not agreed on the number of arbitrators, the arbitral tribunal shall consist of three arbitrators. The default provisions in the UNCITRAL Rules and SCC Rules are not that surprising considering that the respective arbitration laws they are inspired by (the Model Law and the Swedish Arbitration Act), also refer to default three-member tribunals, as explained above.

Other efficiency promoting regulative issues are specific time limits that have been set in institutional rules (likely the essence of many potential disputes). For instance, according to Article 5(1) of the ICC Rules, the answer to the request for arbitration shall be submitted within 30 days from the receipt of the request from the Secretariat. A similar 30-day time limit is in Article 4 of the UNCITRAL Rules and a 28-day time limit from the commencement of the arbitration in Article 2.1 of the LCIA Rules.

Arbitration rules also contain provisions as to the delivery of the award. According to Article 30(1) of the ICC Rules, the time limit within which the arbitral tribunal must render its final award is six months. A similar six-month limit for making the final award has also been set in Article 37 of the SCC Rules.

Another way of setting an efficient time for rendering the award is the one chosen by the LCIA. Pursuant to Article 15.10 of the LCIA Rules, the tribunal is required to make its final award 'as soon as reasonably possible' after the last submission.

The ICC Rules have taken the efficient award drafting to the next level. The Rules impose on the arbitral tribunal the obligation to inform the ICC Secretariat and the parties after the last hearing of the date by which the tribunal expects to submit its draft award for the ICC Court's scrutiny. Similarly, the tribunal arbitrating under LCIA Rules must also notify the parties and LCIA Registrar of its timetable for considering, drafting and issuing the award.

Article 14.1 of the LCIA Rules also aims for proactive arbitrator efficiency by requiring that the tribunal make contact with the parties within 21 days of its formation, to begin clarifying the issues in dispute and setting out the procedure. This requirement is similar to the Terms of Reference peculiarity contained in Article 23 of the ICC Rules, and the tribunal's obligation to convene a prompt case management conference 55 and a procedural timetable. ${ }^{56}$

Another example related to explicit time limits provisions in arbitration are the 'expedited procedures' many institutions have included in their rules. The expedited proceedings may be advantageous when the dispute is of simpler nature, without a lot of written evidence or if the dispute is of a small monetary value. For instance, the SCC has a separate set of rules for expedited arbitrations. According to them, the parties may submit a limited number of submissions and shorter deadlines are applied in the expedited procedure than those in the procedure under the Arbitration Rules. More

52 With a minor Investor-State Arbitration related addition in 2013.

53 See Article 7(1), UNCITRAL, UNCITRAL Arbitration Rules (as revised in 2010) (UNCITRAL Arbitration Rules).

54 Stockholm Chamber of Commerce (SCC), Arbitration Rules (2010) in force as of 1 January 2010 (SCC Rules).

55 Article 24(1), ICC Rules.

56 Article 24(2), ICC Rules. 
importantly, Article 36 of the SCC Expedited Arbitration Rules ${ }^{57}$ provides for a threemonth time limit for rendering the award, from the date upon which the arbitration was referred to the Arbitrator.

The examples described above do not intend to be an exhaustive list of the techniques and tools available to promote efficiency in arbitration. Specific provisions in laws and arbitration rules, guidelines, reports and 'best practices' will play an important role as the attitude of all the parties involved in the arbitration. Party representatives, the parties themselves, their in-house counsels, the arbitral tribunals, and the institution share different levels of responsibility in the efficient management of the arbitration.

\section{III.2. Tribunal's Discretional Efficiency}

Let us turn to the second category of efficiency tools in arbitration and, more specifically, the tribunals' discretion (and duty) over procedural efficiency. Arbitral tribunals' general procedural discretion has been included in many arbitration laws and rules in order to ensure effective case management. ${ }^{58}$

The ICC Rules have, among others, a new Article 22(1) under which the arbitral tribunal and the parties are to 'make every effort to conduct the arbitration in an expeditious and cost-effective manner having regard to the complexity and value of the dispute'. Moreover, after consulting the parties, the arbitral tribunal may adopt such procedural measures as it considers appropriate in order to ensure effective case management. ${ }^{59}$ Thus, the rules truly provide flexibility for the proceedings empowering the tribunal to proportionally assess the dispute's complexity and value to the process. ${ }^{60}$

For the exercise of good-management discretion, Appendix IV of the ICC Rules lists different techniques for the tribunal to use to control time and cost of the arbitration. Thus, tribunals in ICC arbitrations are vested with discretionary powers, but also provided with means of expressing that discretion in an efficient manner. Nothing stops tribunals under other institutional rules or ad hoc arbitrations from following the guidelines provided by the said Appendix. At the end of the day, those techniques simply aim to avoid unnecessary oral hearings, limiting the length of written submissions and overlapping oral witness testimonies in any arbitration. It has been argued that none of these measures would actually result in anything innovative, as the efficiency objective is not a new concept. ${ }^{61}$ One could also argue to the contrary, that the inclusion of these means of effective case management into the arbitration rules contributes to the development of norms (soft law), and bolsters predictability and harmonised international standards.

Although arbitral tribunals have at their disposal a plethora of tools and discretional powers to conduct arbitrations in an efficient way, and are always respectful of essential procedural guarantees, in practice, conflicts between efficiency and procedural fairness do exist. When that happens, arbitrators are put to the test on their ability to find that delicate balance that will safeguard the recognition and enforceability of their award.

57 SCC, Rules for Expedited Arbitration (2010) in force as of 1 January 2010 (SCC Rules) at $<$ sccinstitute.com/dispute-resolution/rules/> (accessed 10 May 2015) (Expedited Arbitration Rules).

58 See eg., Article 19, Model Law; Article 17(1), UNCITRAL Arbitration Rules; Article 22(2), ICC Rules; Article 19(1), SCC Rules; Article 25.1, FAI Rules.

59 Article 22(2), ICC Rules.

60 Grierson, J and van Hooft, A, Arbitrating under the 2012 ICC Rules, (Kluwer Law International, Leiden, 2012), 13.

$61 \quad I d, 14$. 


\section{Two Sides of the Same Coin?}

Dr Joerg Risse introduced a dilemma of the 'magic triangle', a familiar concept to those within the world of investments, which is also relevant in the context of arbitration. The triangle's corners represent the desired objectives of arbitration, which cannot be reconciled simultaneously in a single arbitration. Only two corners can be picked at once. Risse's corners are 'time efficiency', 'cost savings' and 'quality of the award'. ${ }^{62}$ As described above, the first two of these cornerstones of arbitration can be categorised to the one and same concept of arbitral efficiency. Thus, the authors have repurposed the triangle to trying to find the balance between the corners of 'party autonomy', 'due process' and 'efficiency'.

Because arbitration awards are final and binding and they cannot be appealed on their merits, the mandatory procedural provisions have a crucial weight in the safeguarding system of judicial review of arbitral awards. Therefore, the mere objective of efficient proceedings cannot easily outweigh due process. ${ }^{63}$ Thus, the issue is more likely to be defining the scope of applying both concepts at the same time.

For example, under English law, arbitral discretion is exercised in the shadow of party autonomy and also Section 68 of the English Arbitration Act, which permits a party to the arbitration to challenge the award on the ground of serious irregularity affecting the proceedings (the tribunal or the award). Serious irregularities include, among others, the arbitrator's failure to comply with procedural fairness and also with efficiency. ${ }^{64}$ Efficiency aims to promote the optimum administration of justice, but it is only in extreme cases of 'inefficiency' that an award may be refused recognition or enforcement. This is when inefficiency has caused 'substantial injustice' to the applicant. The possibility that an arbitrator be less efficient than the parties expected remains a risk assumed by them. ${ }^{65}$

In some cases, by trying to balance out the duty to treat the parties fairly (due process) and the duty to promote efficiency, arbitral tribunals have been unable to succeed in their duty to render an enforceable award. An example of the difficulties arbitral tribunals face when weighing procedural fairness and efficiency is the Caribbean Niquel v Overseas Mining case. ${ }^{66}$ In the case, the parties entered into a joint venture with the objective of operating a mine. A dispute arose before the mine had even become operative. As a result, one of the parties commenced arbitration and sought damages pursuant to the theory of 'lost profit'. In its decision, the tribunal indeed awarded the claimant a compensation for damages, but based on the theory of 'lost chance'. In setting aside the proceedings, the court held that the award violated the parties right to be heard (due process), because the

62 Risse, J, "Ten Drastic Proposals for Saving Time and Costs in Arbitral Proceedings", 23(3) Arbitration International (2013) 4.

63 Born, supra nt 6, 2124.

64 Section 33, Arbitration Act 1996, England. In a similar vein, Section 21, Swedish Arbitration Act stipulates that arbitrators shall handle the dispute in a speedy manner, although its non-observance would not, per se, constitute a ground for setting aside the award.

65 Park, WW, "The Four Musketeers of Arbitral Duty: Neither One-for-all nor All-for-one", in Derains, Y and Lévy, L, eds, Is Arbitration Only as Good as the Arbitrator? Status, Powers and Role of the Arbitrator (Dossiers, ICC Institute of World Business Law, 2011), 25.

66 Paris Court of Appeals, La Societe Commercial Caribbean Niquel v La Societe Overseas Mining Investments Ltd, 25 March 2010, Chamber 1, 08/23901. 
parties had not had an adequate opportunity to comment on the different (and not invoked) legal basis for the calculation of damages. ${ }^{67}$

Prior to making its decision, and in order to respect due process, the tribunal should have (supposedly) scheduled a hearing or a set of written submissions for the parties to comment on the non-alleged legal theory of lost chance. Unfortunately this would have affected, at least, the tribunal's duty to make a decision without unnecessary delays and create extra expenses - ie limit overall efficiency. More importantly, the arbitrators would have risked raising doubts as to its impartiality, because it could have been interpreted as if they were siding with one of the parties (claimant) and advancing perhaps a more appropriate legal basis for its claim.

Understandably, the tribunal may have tried to avoid awarding damages based on grounds (lost profit) that would have certainly not compensated the correct amount (if any at all), for an enterprise that had not even begun to operate. In any case, the arbitrators' apparent intention to enhance efficiency betrayed a more fundamental duty, which is to ensure the procedural fairness needed to render an enforceable award.

Another example of the tensions between due process and efficiency is the consolidation of multiple disputes into a single arbitration. In general terms, consolidation of two or more claims into one single procedure involving all related parties and disputes, aims to avoid repetition or duplication of the same evidentiary materials, to minimise costs and to avoid the hassles of contradicting outcomes. ${ }^{68}$

A first decisive question is whether any related claims can (or should) be consolidated into one proceeding. An example may serve again to illustrate the tension between efficiency and due process. In the Stolt-Nielsen $v$ Animal Feeds case, ${ }^{69}$ there were multiple actions by different parties against several ship-owners, under similar arbitration agreements. The claimants requested a single, consolidated proceeding to address their combined claims. The respondents opposed to it. In a partial award, the tribunal construed the arbitration agreements so as to allow the consolidation of claims. In doing so, it bore in mind that certain preconditions had to be met, such as common questions of law and fact among the different claims. In vacating the award, the US Supreme Court held that the arbitrators had exceeded their powers by imposing its own policy choice rather than deciding pursuant to the applicable law. ${ }^{70}$ Even if the proceedings may be seen as more efficient, the court understood that the respondent's procedural right not to be subjected to a class (consolidated) arbitration, to which they had not consented, had to be respected.

Again, this decision shows that even efficient case management with the best intentions requires observance to (sacrosanct) procedural guarantees of due process. This is so even if efficiency has to take a step back in favour of some delays and further costs.

67 Id, confirmed by decision Cour de Cassation, Première chambre civile, La societe Overseas Mining Investments Limited v La societe Commercial Caribbean Niquel, 29 June 2011, Arrêt No 785 (10-23.321).

68 However, consolidation may end up being less efficient and more costly for a party with a small claim, the settlement of which is likely to take longer and is, accordingly, less cost-effective.

69 US Supreme Court, Stolt-Nielsen SA v Animal Feeds International Corp, 27 April 2010, 559 US 662.

$70 \quad I d, 676,17702$. 


\title{
V. Conclusion
}

Observance of the procedural fairness (procedural due process) is embedded in arbitration as a one-stop mechanism to determine disputes, as a venue that substitutes the parties' constitutional right to seek justice from a national court. As violations of the basic procedural fairness give rise to sanctions, arbitrators are (and should be) concerned with identifying the relevant rule of due process applicable at the different stages of the arbitral proceedings. While the sources may vary, the core of the principle of due process will likely remain the same, but its specifications will again need to fluctuate and adjust to different legal cultures. The existence of different cultural baselines implies that a procedural decision by the arbitrators may deviate from one of the parties' understanding of procedural integrity. Practices that constitute an expression of procedural fairness in one legal system may be not used in another due to being unethical or even prohibited.

With the aim of promoting an optimum administration of justice outsourced from the State, arbitrators also have a duty towards efficiency. Although the duties to observe procedural guarantees of due process and efficient administration of the arbitral proceedings may face intricate tensions, procedural fairness must prevail for the arbitral award to be recognised and enforceable. Inefficiency may not carry serious consequences on the award, unless it in fact causes serious injustice - at least under certain arbitration laws. Therefore, due process and efficiency can be seen as the two sides of the same coin. The arbitrators' mission then is to find the delicate equilibrium between the two.

Yet, as William Park observed, ${ }^{71}$ the penalty for a breach of an arbitrator's duty of fairness carries a certain irony. The sanctions do not fall directly on the arbitrator who breached his or her duty. Instead, the price of the arbitrators' misconduct falls on the prevailing party, which must suffer annulment of an award for breach of fundamental procedural integrity.

\author{
www.grojil.org
}

71 Park, supra nt 65, 25. 